\title{
Production of more durable and sustainable concretes using volcanic scoria as cement replacement
}

\author{
A.M. al-Swaidani $₫$ \\ Faculty of Architectural Engineering, Arab International (Formerly European) University, (Damascus, Syria) \\ \aydlswaidani@yahoo.fr; a-swaidani@aiu.edu.sy
}

Received 16 January 2016 Accepted 13 September 2016 Available on line 10 March 2017

\begin{abstract}
The objective of the study is to investigate strength and durability-related properties of volcanic scoria-based cements. Compressive and tensile strength development of mortars and concretes containing volcanic scoria with replacement levels ranging from 10 to $35 \%$ was investigated. Water permeability, chloride penetrability and porosity of concretes cured for 2, 7, 28, 90 and 180 days were also examined. Results revealed that volcanic scoria could be suitable for making blended cements. The strength of mortar/concrete containing volcanic scoria was lower than that of plain cement mortar/concrete at all ages. However, at 90 day curing, the strengths of volcanic scoria-based mortars/concretes were comparable to those of plain cement. In addition, water permeability, chloride penetrability and porosity of scoria-based concretes were much lower than those of plain concrete. Further, the results were statistically analysed and estimation equations have been developed to predict the studied properties. SEM/EDX analysis was employed, as well.
\end{abstract}

KEYWORDS: Pozzolane; Blended cement; Mechanical properties; Durability; SEM

Citation/Citar como: al-Swaidani, A.M. (2017) Production of more durable and sustainable concretes using volcanic scoria as cement replacement. Mater. Construcc. 67 [326], e118 http://dx.doi.org/10.3989/mc.2017.00716

RESUMEN: Producción de hormigones más durables y sostenibles utilizando escoria volcánica como sustitutivo de cemento. El objetivo del estudio fue investigar la resistencia y durabilidad de cementos basados en escoria volcánica. El desarrollo de resistencias a flexión y compresión, se estudió en morteros y hormigones con escoria volcánica en porcentajes de reemplazo desde 10 al 35\%. Se realizaron ensayos de permeabilidad al agua, penetración de cloruros y porosidad de los hormigones a las edades de 2, 7, 28, 90 y 180 días. Los resultados revelaron que la escoria volcánica podría ser adecuada para la fabricación de cementos con adiciones. La resistencia de morteros/hormigones que contiene escoria volcánica fue menor que la de los correspondientes morteros u hormigones sin adición a todas las edades. Sin embargo, a los 90 días de curado, las resistencias de los morteros/ hormigones con escoria fueron comparables con las del cemento sin adición. La permeabilidad al agua, penetrabilidad de cloruros y porosidad de los hormigones con escoria fueron mucho más bajos que los del correspondiente hormigón sin escoria. Los resultados se analizaron estadísticamente y las ecuaciones de estimación se han desarrollado para predecir las propiedades estudiadas. También se empleó el análisis SEM/EDX.

PALABRAS CLAVE: Puzolana; Cementos con adiciones; Propiedades mecánicas; Durabilidad, MEB

ORCID ID: A.M. al-Swaidani (http://orcid.org/0000-0001-9414-0482)

Copyright: (C) 2017 CSIC. This is an open-access article distributed under the terms of the Creative Commons Attribution License (CC BY) Spain 3.0.

\section{INTRODUCTION}

Production of Portland cement; the principal binder in concrete, is a major contributor to greenhouse gas emissions that are implicated in global warming and climate change. The worldwide cement production accounts for almost $7 \%$ of the total world $\mathrm{CO}_{2}$ emissions $(1,2)$. Depending on the carbon content of fossil fuels used for clinkering, nearly 0.8 to 1.0 tonne of $\mathrm{CO}_{2}$ is directly released 
from cement kilns during the manufacture of one tonne of clinker $(1,3)$. In addition, about 4 to 7 GJ of energy is required to produce one tonne of cement $(1,2)$. Furthermore, the aggressive environments may shorten significantly the service life of the concrete structure. So, finding a solution to increase the durability of concrete structures and thus the sustainability of the concrete seems to be desirable for sustainable development.

Probably one of the most effective means of decreasing both energy consumption and the production of greenhouse gases is to substitute supplementary cementitious materials (SCMs) for a portion of the Portland cement. There are a number of SCMs available, several of which are already used extensively in the industry (2). They are all pozzolanic materials; that is, fine siliceous materials that react at ambient temperatures with the lime released during the hydration of $\mathrm{C}_{2} \mathrm{~S}$ and $\mathrm{C}_{3} \mathrm{~S}$ to form a secondary C-S-H (2). Furthermore, the inclusion of these materials which can be categorized as natural or artificial enhances the concrete durability due to their filler effect and pozzolanic reaction (4).

Natural pozzolans are being widely used as substitute for Portland cement because of their ecological, economical and performance-related advantageous properties (5-12). After thousands of years, natural pozzolan-containing concretes are still used today owing to their good mechanical and durability properties (13). Syria has important volcanic areas. More than $30000 \mathrm{~km}^{2}$ of the country is covered by Tertiary and Quaternary-age volcanic rocks (14), among which volcanic scoria occupies important volume with estimated reserves of about $0.75 \times 10^{9}$ tonnes (15). However, its potential use in making concrete is not well established. The cement produced in the country is almost of CEM I, although an addition of volcanic scoria up to $5 \%$ was frequently used in most local cement plants. Hence, less than 300000 tonnes of these pozzolans are only exploited annually (the annual production of Portland cement in Syria is about 6 million tonnes) (16).

Although there are numerous studies on using natural pozzolan as cement replacement (5-12), few works on studying volcanic scoria were reported in the literature $(7,12)$. Furthermore, no detailed research was conducted in the past to investigate the potential use of volcanic scoria in production of blended cements in Syria. The present work reports a part of the first detailed research in the country to investigate the potential utilization of volcanic scoria as cement replacement in producing Portland-pozzolan cements. This investigation has been conducted through a series of experiments. Mechanical strength development, water permeability, chloride penetrability and porosity of concretes containing different scoria contents (10 to $35 \%$ ) have particularly been investigated.
Physical, chemical and mineralogical analyses of volcanic scoria and blended cements have been reported, as well.

The importance of the present study can be summarized in the following points:

(i) Studying the strength development of both mortar and concrete systems containing volcanic scoria-based binders with the same water-binder $(w / b)$ ratio was not probably tackled before. Further, an attempt to correlate the compressive strength of concrete with that of mortar could be considered a good approach.

(ii) The paper tries to investigate the mechanical strengths and some permeability-related properties of volcanic scoria-based concretes after five curing times (two early ages; i.e. 2 and 7 day curing, 28 day standard curing and two later ages; i.e. 90 and 180 day curing). Such an investigation might not be found in the literature on using volcanic scoria as cement replacement. In addition, prediction of these properties depending on the curing time and the replacement level of volcanic scoria could also be considered a new approach.

(iii) The replacement of Portland cement by ground volcanic scoria could significantly minimize the quantity of the released $\mathrm{CO}_{2}$ and the consumed energy. Furthermore, this substitution can also achieve benefits relating to concrete performance.

(iv) The study is the first of its kind in Syria. However, it is not limited to the country. It can be applied to other areas of similar geology, e.g. Harrat al-Shaam; a volcanic field covering a total area of some $45000 \mathrm{~km}^{2}$, third of which is located in the country (Figure 1). The rest covers parts from Jordan and Saudi Arabia.

(v) As Syria begins preparations for the huge rebuilding work after the conflict comes to its end, the encouraging results of using volcanic scoria can be considered a motivation of other studies, such as use of volcanic scoria in improvement of the properties of recycled aggregate concrete which are expected to be inevitable construction material during the post-war rebuilding in the country.

\section{MATERIALS AND METHODS}

\subsection{Materials}

The volcanic scoria used in the experiments was quarried from Dirat-at-Tulul site, at about $70 \mathrm{~km}$ southeast of Damascus as shown in Figure 1. The mineralogical analysis showed the scoria is mainly composed of amorphous glassy ground mass, vesicles, plagioclase and olivine. Thin sections of the investigated volcanic scoria are shown in Figure 2. The chemical analysis of scoria used in the study is summarized in Table 1. This analysis was carried out by means of wet chemical analysis specified in EN 196-2. 
(a)

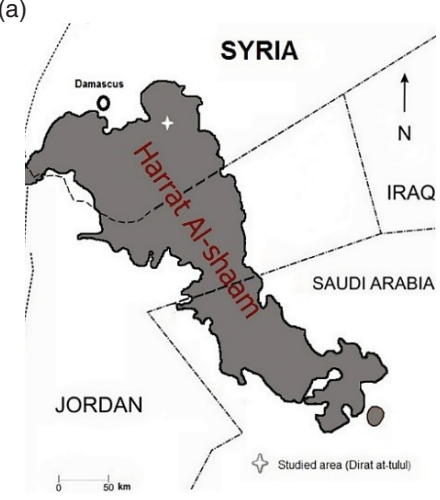

(c)

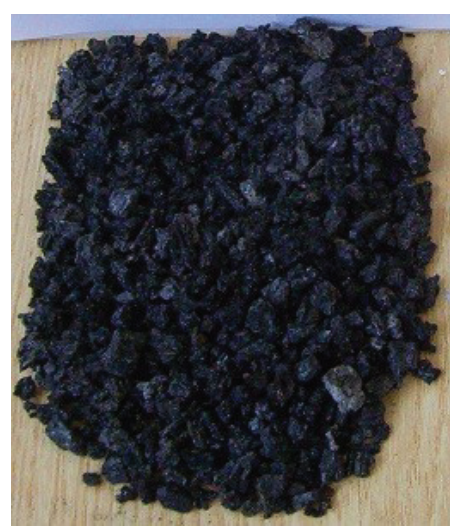

(b)

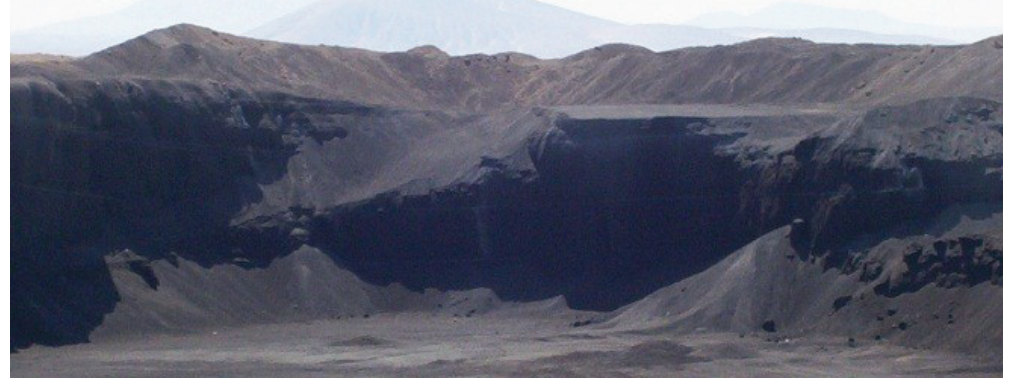

(d)

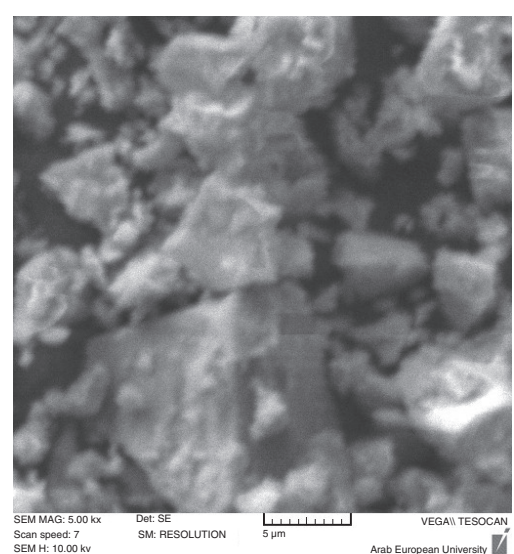

Figure 1. Map of Harrat al-Shaam, photo of the studied site and photo of the used scoria aggregate and the micrograph of the ground scoria. a. Map of the volcanic area "Harrat al-Shaam" and the studied site; b. The studied volcanic scoria quarry, some volcanic scoria cones are shown behind; c. the studied scoria aggregate; d. SEM micrograph of the studied ground volcanic scoria.

(a)

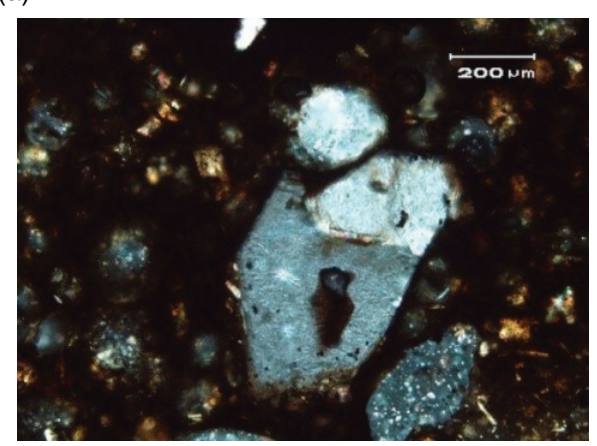

(b)

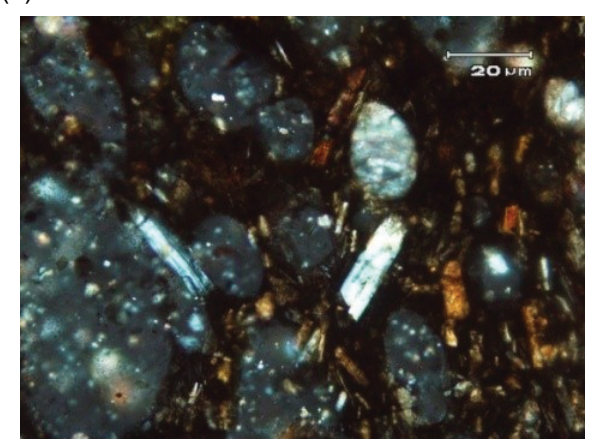

FIGURE 2. Thin sections of the scoria. a. Microphenocryst of Olivine in volcanic glass matrix with vesicles, some of which are filled with white minerals; b. Microphenocrysts of elongated plagioclase in volcanic glass matrix with vesicles, some of which are filled with white minerals.

Seven binder samples were prepared in accordance with EN 197-1; one plain Portland cement CEM I (control), three CEM II/A-P samples with three replacement levels (10, 15 and 20\%), and three CEM II/B-P samples with three replacement levels $(25,30$, $35 \%$ ), respectively. According to EN 197-1, CEM I and CEM II refer to two different types of cement, i.e. ordinary Portland cement and Portland-composite cement, respectively; A-P and B-P refer to the percentage of natural pozzolan in cement, i.e. 6-20\% and $21-35 \%$, respectively. All replacements were made by mass. Five percent of gypsum was added to all these binder samples. The clinker was obtained from Adra Cement Plant, Damascus, Syria. Chemical analysis of clinker and gypsum is shown in Table 1. All samples were ground by a laboratory grinding ball mill 
TABLE 1. Chemical composition of the used materials

\begin{tabular}{|c|c|c|c|c|c|}
\hline \multirow{2}{*}{$\begin{array}{l}\text { Chemical composition } \\
\text { (by mass, \%) }\end{array}$} & \multicolumn{5}{|c|}{ Materials } \\
\hline & Scoria & Clinker & Gypsum & Dolomite aggregate & Natural sand \\
\hline $\mathrm{SiO}_{2}$ & 46.52 & 21.30 & 0.90 & 0.42 & 93.39 \\
\hline $\mathrm{SiO}_{2 \text { (reactive) }}$ & 42.22 & - & - & - & - \\
\hline $\mathrm{Al}_{2} \mathrm{O}_{3}$ & 13.00 & 4.84 & 0.07 & 0.38 & 0.57 \\
\hline $\mathrm{Fe}_{2} \mathrm{O}_{3}$ & 11.40 & 3.99 & 0.10 & 0.10 & 0.24 \\
\hline $\mathrm{CaO}$ & 10.10 & 65.05 & 32.23 & 31.40 & 1.70 \\
\hline $\mathrm{CaO}_{\mathrm{f}}$ & - & 2.1 & - & - & - \\
\hline $\mathrm{MgO}$ & 9.11 & 1.81 & 0.20 & 20.46 & 0.20 \\
\hline $\mathrm{SO}_{3}$ & 0.27 & 0.25 & 45.29 & 0.18 & 1.15 \\
\hline Loss on ignition & 2.58 & - & 21.15 & 46.48 & 2.52 \\
\hline $\mathrm{Na}_{2} \mathrm{O}$ & 2.14 & 0.60 & - & 0.06 & 0.06 \\
\hline $\mathrm{K}_{2} \mathrm{O}$ & 0.77 & 0.28 & - & 0.30 & 0.05 \\
\hline $\mathrm{Cl}^{-}$ & $<0.1$ & 0.05 & - & 0.021 & 0.017 \\
\hline $\begin{array}{l}\text { Pozzolan activity index } \\
\text { [ASTM C 618] }\end{array}$ & $\begin{array}{l}79 \text { (at } 7 \text { days) } \\
85 \text { (at } 28 \text { days) }\end{array}$ & & & & \\
\hline
\end{tabular}

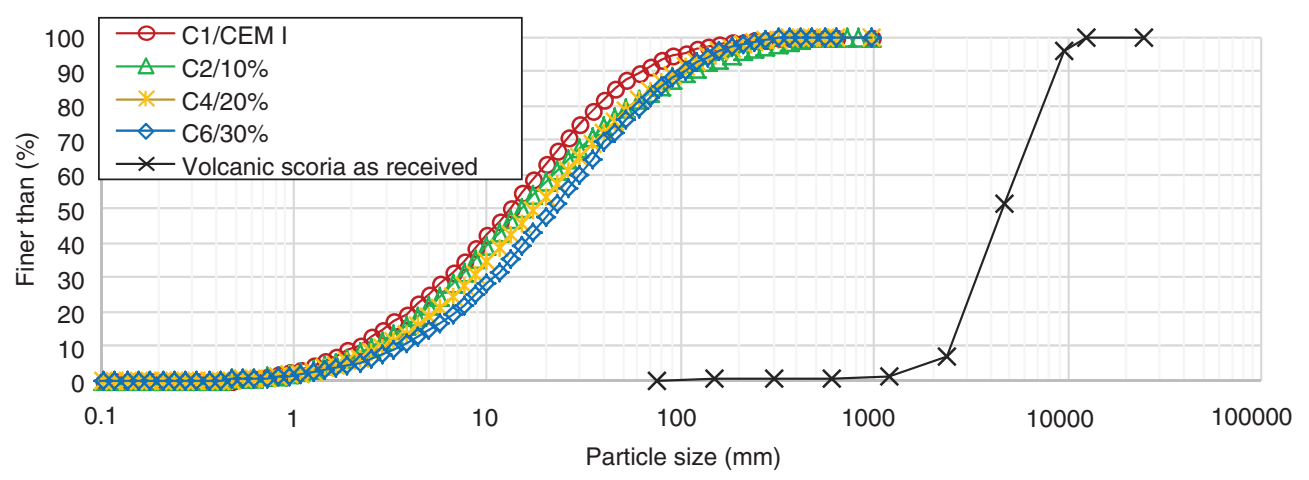

FIGURE 3. Particle size distributions of volcanic scoria« as received », plain cement and some blended cements.

of $25 \mathrm{~kg}$ raw mix capacity into a Blaine fineness of $3200 \pm 50 \mathrm{~cm}^{2} / \mathrm{g}$ which is a customary value in cement production. This grinding process was adopted because it requires less energy than separate grinding (17). The Blaine fineness was measured using air permeability method in accordance with the European standard EN 196-6. The particle size distributions of the binders were obtained using Malvern Mastersizer 2000; a laser particle size analyzer. Figure 3 shows the particle size distribution for some blended cements used in the investigation. The chemical and some physical properties of the binder samples produced for this study are shown in Table 2. CEM I (the control sample) was designated as C1/CEM I, whereas scoria-based binders were designated according to the replacement level. For instance, $\mathrm{C} 2 / 10 \%$ and $\mathrm{C} 7 / 35 \%$ refer to the binders containing $10 \%$ and $35 \%$ of volcanic scoria, respectively.

Seven mortar specimens were prepared using the investigated binders and sand meeting the requirements of ASTM C778. In all mixtures, binder: sand ratio was kept constant as $1: 2.75$ by weight. Waterbinder ratio (w/b ratio) was also kept constant for all mixtures at 0.5 . After being kept in a curing cabinet $(\mathrm{RH} \sim 95 \%)$ for 24 hours, the mortar specimens were demolded and kept in lime-saturated water at $20 \pm 2{ }^{\circ} \mathrm{C}$ until the time of testing.

Seven concrete mixes were prepared using a grading of aggregate mixtures kept constant for all concrete mixes. Aggregates used in the study were crushed dolomite with natural sand added. Chemical composition and some physical properties of the aggregates are illustrated in Table 1 and Figure 4, respectively. Their quantities in $1 \mathrm{~m}^{3}$ concrete mix based on the oven-dry condition were as follows: $585.5 \mathrm{~kg}$ of coarse aggregate, $585.5 \mathrm{~kg}$ of medium-size aggregate, $467.5 \mathrm{~kg}$ of crushed stone sand and $312.5 \mathrm{~kg}$ of natural sand. All concrete mixes were designed to have a water-binder ratio of 0.5 and a slump of $150 \pm 20 \mathrm{~mm}$. Superplasticizer of "type F" (ASTM C494) was added. Concrete cubes $(150 \mathrm{~mm})$ were cast for the determination of 
Production of more durable and sustainable concretes using volcanic scoria as cement replacement $\bullet 5$

TABLE 2. Chemical, physical and mechanical properties of plain and blended cements

\begin{tabular}{|c|c|c|c|c|c|c|c|}
\hline \multirow{2}{*}{$\begin{array}{l}\text { Chemical composition } \\
(\%)\end{array}$} & \multicolumn{7}{|c|}{ Chemical properties of plain and blended cements } \\
\hline & C1/CEMI & $\mathrm{C} 2 / 10 \%$ & $\mathrm{C} 3 / 15 \%$ & $\mathrm{C} 4 / 20 \%$ & $\mathrm{C} 5 / 25 \%$ & $\mathrm{C} 6 / 30 \%$ & $\mathrm{C} 7 / 35 \%$ \\
\hline $\mathrm{SiO}_{2}$ & 20.69 & 21.59 & 22.35 & 23.25 & 24.00 & 24.33 & 24.61 \\
\hline $\mathrm{Al}_{2} \mathrm{O}_{3}$ & 5.09 & 5.20 & 5.68 & 5.73 & 6.55 & 6.80 & 7.39 \\
\hline $\mathrm{Fe}_{2} \mathrm{O}_{3}$ & 4.23 & 4.75 & 4.79 & 5.15 & 5.43 & 5.47 & 6.31 \\
\hline $\mathrm{CaO}$ & 60.62 & 58.21 & 55.18 & 53.05 & 50.30 & 48.00 & 44.84 \\
\hline $\mathrm{MgO}$ & 2.46 & 2.66 & 3.23 & 3.39 & 3.87 & 4.11 & 4.63 \\
\hline $\mathrm{SO}_{3}$ & 2.26 & 2.31 & 2.20 & 2.20 & 2.30 & 2.26 & 2.55 \\
\hline Loss on ignition & 1.41 & 1.40 & 1.43 & 1.37 & 1.47 & 1.48 & 1.60 \\
\hline $\mathrm{Na}_{2} \mathrm{O}$ & 0.60 & 0.71 & 0.83 & 0.94 & 1.07 & 1.16 & 1.31 \\
\hline $\mathrm{K}_{2} \mathrm{O}$ & 0.35 & 0.39 & 0.43 & 0.46 & 0.50 & 0.53 & 0.57 \\
\hline $\mathrm{Cl}^{-}$ & 0.023 & 0.021 & 0.022 & 0.019 & 0,018 & 0.019 & 0.019 \\
\hline \multirow[t]{2}{*}{ Insoluble Residue } & 1.03 & 1.58 & 2.09 & 2.51 & 3.48 & 4.08 & 5.33 \\
\hline & \multicolumn{7}{|c|}{ Physical properties of plain and blended cements } \\
\hline Specific gravity & 3.13 & 3.09 & 3.05 & 3.02 & 2.99 & 2.98 & 2.96 \\
\hline Initial setting (min) & 151 & 153 & 153 & 153 & 152 & 153 & 158 \\
\hline Final setting (min) & 178 & 179 & 180 & 180 & 179 & 181 & 188 \\
\hline Water demand $(\%)$ & 25.1 & 25.2 & 25.2 & 25.4 & 25.4 & 25.4 & 25.5 \\
\hline Soundness (mm) & 0.6 & 0.7 & 0.8 & 0.8 & 0.9 & 1.1 & 0.9 \\
\hline $\begin{array}{l}\text { Residue on } 45 \mu \mathrm{m} \\
\text { sieve }(\%)\end{array}$ & 13.6 & 14.3 & 14.8 & 15.2 & 16.1 & 17.0 & 17.9 \\
\hline $\begin{array}{l}\text { Residue on } 90 \mu \mathrm{m} \\
\text { sieve }(\%)\end{array}$ & 6.4 & 6.2 & 6.4 & 6.5 & 6.7 & 6.9 & 6.8 \\
\hline
\end{tabular}

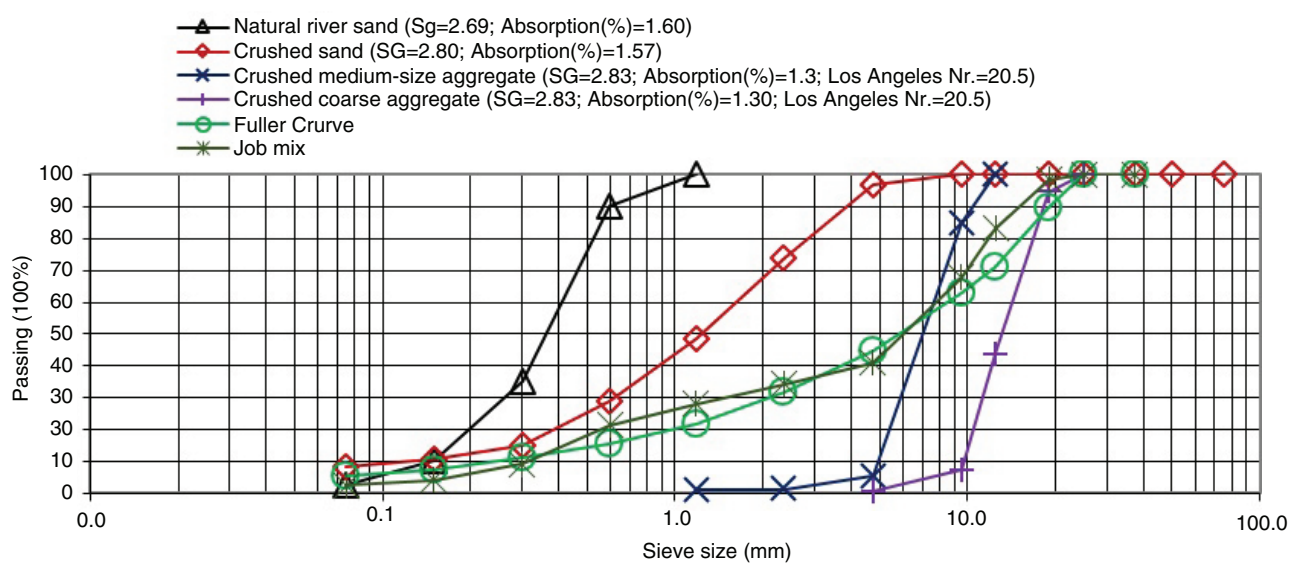

FIGURE 4. Grading curves of the concrete aggrgates with some physical properties.

mechanical strengths (compressive and tensile splitting strengths) and water permeability. Concrete cylinders $(100 \mathrm{~mm} \times 200 \mathrm{~mm})$ and $(75 \mathrm{~mm} \times 150 \mathrm{~mm})$ were also cast for evaluation of the chloride penetrability and the porosity of the concretes, respectively.

\subsection{Methods}

Water requirements, setting times and soundness of all binder paste specimens were determined in accordance with EN 196-3. The compressive and flexural strength development of mortars was determined on $40 \times 40 \times 160 \mathrm{~mm}$ prismatic specimens, in accordance with EN 196-1, at ages of 2, 7, 28, 90 and 180 days. The compressive and splitting strengths of concretes were conducted on 150 $\mathrm{mm}$ cubic concrete specimens in accordance with ISO 4012 and 4108, at ages of 2, 7, 28, 90 and 180 days. Concrete permeability measured in terms of depth of water penetration was carried out as per the standard EN 12390-8. The results shown in this paper are the average penetration depth. The rapid 
(a)

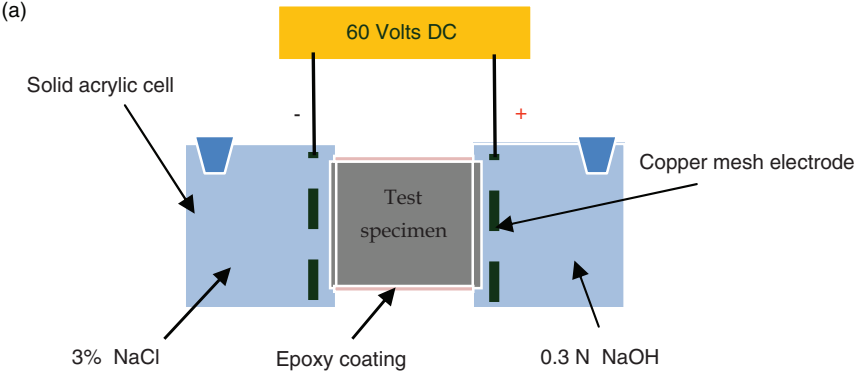

(b)

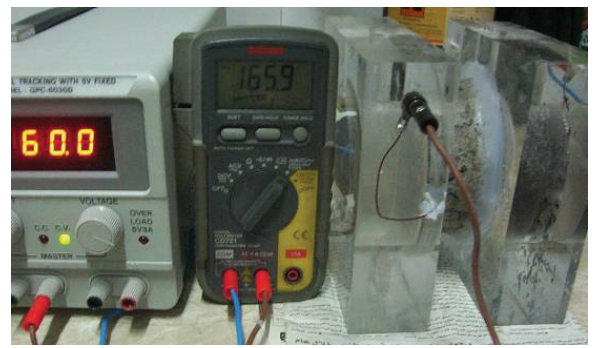

FIGURE 5. Experimental setup of rapid chloride penetration test. a) Schematic representation of experimental setup of rapid chloride penetration test. b) View of experimental setup (one of current readings for $\mathrm{C} 6 / 30 \%$ specimen).

chloride penetrability $(\mathrm{RCP})$ test was conducted in accordance with ASTM C1202. The set-up of RCP test is illustrated in Figure 5. Three cylinder specimens of each concrete mix were tested after 2, 7 , 28, 90 and 180 days curing. Porosity measurements were conducted using vacuum saturation method in accordance with RILEM CPC 11.3. The values reported in the results represent the average of six readings for compressive strength test and the average of three readings for all other tests.

\section{RESULTS AND DISCUSSION}

\subsection{Properties of volcanic scoria and blended cements}

As seen from Table1, volcanic scoria is considered as suitable material for use as pozzolan. It satisfied the standard requirements for such a material by having a sum of $\mathrm{SiO}_{2}, \mathrm{Al}_{2} \mathrm{O}_{3}$ and $\mathrm{Fe}_{2} \mathrm{O}_{3}$ of more than $70 \%$, a $\mathrm{SO}_{3}$ content of less than $4 \%$ and a loss on ignition (LOI) of less than 10\% (ASTM C618). reactive $\mathrm{SiO}_{2}$ content was more than $25 \%$, as well (EN 197-1). In addition, it had a strength activity index with Portland cement (PC) higher than the values specified in ASTM C618. The chemical properties of volcanic scoria-based binders, Table 2, were also in conformity with the standard requirements (ASTM C595). Their contents of $\mathrm{MgO}$ and $\mathrm{SO}_{3}$ were less than $6 \%$ and $4 \%$, respectively. The loss on ignition (LOI) was also less than $5 \%$ as specified in ASTM C595.

\subsection{Physical properties of cement pastes}

The results of water requirements, setting times and soundness are given in Table 2. As it can be seen from the Table 2, there was no significant change in the water content even for the binder containing $35 \%$ of volcanic scoria which increased only by less than 0.5 compared to C1/CEM I. This could be explained by the lubricant effect of volcanic scoria on paste when finely divided (18) and the effect of volcanic scoria shape which was characterized by sharp-edged grains (19) as seen in Figure 1(d).
The results shown in Table 2, revealed that the setting times increased with volcanic scoria replacement level. The effect was more pronounced when the volcanic scoria content was used at 35\% as cement replacement. For example, the highest initial and final setting times at this percentage were $158 \mathrm{~min} \&$ $188 \mathrm{~min}$. This could be due to the pozzolanic reaction between pozzolan and $\mathrm{CH}$ liberated during hydration of $\mathrm{C}_{3} \mathrm{~S}$ and $\mathrm{C}_{2} \mathrm{~S}$ of clinker, which is usually slower than the hydration of cement (20). Some researchers related the delay in setting times when using natural pozzolan with the increase in water requirement (21). It is worthwhile to note that all the scoria-based binders complied with the standard requirements (initial setting time $=45 \mathrm{~min}$ and final setting time $=420 \mathrm{~min}$ ), according to (ASTM C595).

The Results of experiments conducted to see the swelling effects of compounds such as $\mathrm{CaO}$ and $\mathrm{MgO}$ that exist freely in cement are given in Table 2. According to these results, the volume expansions of samples containing volcanic scoria-based binders showed similar values to that of control. Interpretation of these results is currently beyond the understanding of the authors and needs further investigation, although all soundness values were much less than $10 \mathrm{~mm}$ as specified in EN 197-1.

\subsection{Mechanical strength development of mortars/ concretes}

\subsubsection{Compressive strength development of mortars/ concretes}

Strength of concrete is commonly considered its most valuable property, although, in many practical cases, other characteristics, such as durability and permeability, may in fact be more important (22).

Results of compressive strength development of the investigated mortars and concretes are given in Tables 3 and 4, respectively. As expected, all mortars and concretes showed an increase in strength with curing time. Mortar and concrete specimens containing $\mathrm{C} 1 / \mathrm{CEM} \mathrm{I}$ had higher compressive strengths at any curing time compared to volcanic scoria-based binder mortars and concretes. 
Production of more durable and sustainable concretes using volcanic scoria as cement replacement $\bullet 7$

TABLE 3. Compressive and flexural strength development of mortars

\begin{tabular}{|c|c|c|c|c|c|c|}
\hline \multirow[b]{2}{*}{ Binder type } & \multirow[b]{2}{*}{ Strength type } & \multicolumn{5}{|c|}{ Compressive $\left(f_{c m}\right)$ and flexural $\left(f_{t}\right)$ strengths of mortar (MPa)-normalized } \\
\hline & & 2 & 7 & 28 & 90 & 180 \\
\hline \multirow[t]{2}{*}{ C1/CEM I } & $f_{c m}$ & $15.4-100$ & $30.6-100$ & $45.6-100$ & $54.5-100$ & $55.6-100$ \\
\hline & $f_{t}$ & $4.3-100$ & $7.1-100$ & $7.9-100$ & $8.3-100$ & $8.5-100$ \\
\hline \multirow[t]{2}{*}{$\mathrm{C} 2 / 10^{\circ} \%$} & $f_{c m}$ & $14.6-95 \%$ & $29.3-96 \%$ & $44.2-97 \%$ & $53.6-98 \%$ & $54.9-99 \%$ \\
\hline & $f_{t}$ & $4.1-95 \%$ & $7.0-99 \%$ & $7.8-98 \%$ & $8.3-100 \%$ & $8.4-99 \%$ \\
\hline \multirow[t]{2}{*}{ C $3 / 15 \%$} & $f_{c m}$ & $13.9-90 \%$ & $27.1-89 \%$ & $42.3-93 \%$ & $52.7-97 \%$ & $54.2-97 \%$ \\
\hline & $f_{s t}$ & $4.0-93 \%$ & $6.8-96 \%$ & $7.6-96 \%$ & $8.2-99 \%$ & $8.3-98 \%$ \\
\hline \multirow[t]{2}{*}{$\mathrm{C} 4 / 20 \%$} & $f_{c m}$ & $13.6-88 \%$ & $25.4-83 \%$ & $40.6-89 \%$ & $52.1-96 \%$ & $53.5-96 \%$ \\
\hline & $f_{t}$ & $3.7-86 \%$ & $6.4-91 \%$ & $7.5-94 \%$ & $8.0-97 \%$ & $8.1-96 \%$ \\
\hline \multirow[t]{2}{*}{$\mathrm{C} 5 / 25 \%$} & $f_{c m}$ & $12.5-81 \%$ & $23.5-77 \%$ & $37.0-81 \%$ & $51.3-94 \%$ & $53.3-96 \%$ \\
\hline & $f_{t}$ & $3.6-84 \%$ & $6.1-86 \%$ & $7.2-90 \%$ & $7.8-94 \%$ & $8.0-95 \%$ \\
\hline \multirow[t]{2}{*}{ C6/30\% } & $f_{c m}$ & $11.1-72 \%$ & $21.3-70 \%$ & $33.7-74 \%$ & $49.4-91 \%$ & $51.7-93 \%$ \\
\hline & $f_{t}$ & $3.3-76 \%$ & $5.7-81 \%$ & $6.9-87 \%$ & $7.7-96 \%$ & $7.9-93 \%$ \\
\hline \multirow[t]{2}{*}{$\mathrm{C} 7 / 35 \%$} & $f_{c m}$ & $10.1-66 \%$ & $20.0-65 \%$ & $31.6-69 \%$ & $47.6-87 \%$ & $49.5-89 \%$ \\
\hline & $f_{t}$ & $3.1-72 \%$ & $5.4-76 \%$ & $6.6-83 \%$ & $7.4-89 \%$ & $7.8-93 \%$ \\
\hline
\end{tabular}

TABLE 4. Compressive and splitting tensile strength development of concrete

\begin{tabular}{|c|c|c|c|c|c|c|}
\hline \multirow[b]{2}{*}{ Binder type } & \multirow[b]{2}{*}{ Strength type } & \multicolumn{5}{|c|}{ Compressive $\left(f_{c}\right)$ and splitting tensile $\left(f_{s t}\right)$ strengths of concrete (MPa)-normalized } \\
\hline & & 2 & 7 & 28 & 90 & 180 \\
\hline \multirow[t]{2}{*}{$\mathrm{C} 1 / \mathrm{CEM} \mathrm{I}$} & $f_{c}$ & $14.1-100$ & $27.6-100$ & $41.3-100$ & $48.6-100$ & $49.8-100$ \\
\hline & $f_{s t}$ & $1.7-100$ & $3.2-100$ & $4.3-100$ & $4.8-100$ & $5.1-100$ \\
\hline \multirow[t]{2}{*}{$\mathrm{C} 2 / 10 \%$} & $f_{c}$ & $13.2-94 \%$ & $26.3-95 \%$ & $39.8-96 \%$ & $47.9-98 \%$ & $48.5-97 \%$ \\
\hline & $f_{s t}$ & $1.7-98 \%$ & $3.2-101 \%$ & $4.3-99 \%$ & $4.9-101 \%$ & $5.1-99 \%$ \\
\hline \multirow[t]{2}{*}{$\mathrm{C} 3 / 15 \%$} & $f_{c}$ & $12.3-88 \%$ & $23.8-86 \%$ & $37.0-90 \%$ & $45.6-94 \%$ & $47.0-94 \%$ \\
\hline & $f_{s t}$ & $1.6-96 \%$ & $3.1-97 \%$ & $4.1-96 \%$ & $4.9-100 \%$ & $5.0-98 \%$ \\
\hline \multirow[t]{2}{*}{$\mathrm{C} 4 / 20 \%$} & $f_{c}$ & $12.1-85 \%$ & $22.4-81 \%$ & $35.8-87 \%$ & $44.8-92 \%$ & $46.2-93 \%$ \\
\hline & $f_{s t}$ & $1.5-88 \%$ & $2.8-87 \%$ & $4.0-93 \%$ & $4.7-98 \%$ & $5.0-97 \%$ \\
\hline \multirow[t]{2}{*}{ C5/25\% } & $f_{c}$ & $11.1-78 \%$ & $20.6-75 \%$ & $31.9-77 \%$ & $43.9-90 \%$ & $45.4-91 \%$ \\
\hline & $f_{s t}$ & $1.3-79 \%$ & $2.8-88 \%$ & $4.0-92 \%$ & $4.8-98 \%$ & $4.9-96 \%$ \\
\hline \multirow[t]{2}{*}{ C6/30\% } & $f_{c}$ & $9.8-69 \%$ & $18.6-67 \%$ & $29.5-71 \%$ & $41.8-86 \%$ & $43.9-88 \%$ \\
\hline & $f_{s t}$ & $1.3-75 \%$ & $2.6-82 \%$ & $3.7-85 \%$ & $4.6-96 \%$ & $4.9-95 \%$ \\
\hline \multirow[t]{2}{*}{$\mathrm{C} 7 / 35 \%$} & $f_{c}$ & $8.8-62 \%$ & $17.3-63 \%$ & $26.6-64 \%$ & $39.1-81 \%$ & $40.8-82 \%$ \\
\hline & $f_{s t}$ & $1.3-76 \%$ & $2.4-76 \%$ & $3.5-80 \%$ & $4.5-93 \%$ & $4.8-93 \%$ \\
\hline
\end{tabular}

Also, it is seen that the compressive strength of volcanic scoria-based mortars and concretes decreased with the volcanic scoria replacement level for all curing times. For instance, the compressive strength of $\mathrm{C} 1 / \mathrm{CEM} \mathrm{I}$ and $\mathrm{C} 7 / 35 \%$-based mortars and concretes after 7 day curing decreased from 30.6 and $27.6 \mathrm{MPa}$ to 20.0 and 17.3 MPa, respectively. This could be explained by (i) the reduction of cement content in the mix with the increase of volcanic scoria content; i.e. the dilution effect (23) and (ii) the slowness of the pozzolanic reaction (24). However, due to the continuation of this reaction and the formation of a secondary C-S-H, a greater degree of hydration was achieved resulting in strengths after
90 and 180 day curing which were comparable to those of C1/CEM I specimens. For instance, the compressive strength of C6/30\%-based mortar and concrete was found to be $28 \%$ and $31 \%$ lower than C1/CEM I-based specimens after 2 day curing, but this reduction was only $7 \%$ and $12 \%$ after 180 day curing. It is also clearly seen from the results that the significant gain in strength in blended cement mortars and concretes occurred when moving from 28 to 90 day curing times while in C1/CEM I specimens this was noted during the first 28 days. This could be explained by the slow pozzolanic reaction and its progress with age in scoria-based mortars and concretes. 


\subsubsection{Correlation between compressive strength of mortar and compressive strength of concrete}

The correlation between the compressive strength of volcanic scoria-based mortars and the compressive strength of volcanic scoria-based concretes is given in Figure 6. The compressive strength of scoria-based concretes seems to have a close relationship with that of volcanic-scoria-based mortars. A linear regression analysis was conducted to determine the best-fit relationship between the all measured compressive strengths of mortars and concretes for all curing times. The following linear equation was derived based on the analysis with a regression coefficient of 0.99 ; a regression coefficient of more than 0.85 indicates an excellent correlation between the fitted parameters (25) [1]:

$$
f_{c}=0.861 f_{c m}+0.387
$$

where $f_{c}, f_{c m}$ are compressive strength of concrete and mortars in $\mathrm{MPa}$, respectively. So, the compressive strength of concretes at a given curing time can be predicted from a knowledge of the compressive strength of mortar prepared with the same w/b ratio. This linear equation is in good agreement with that reported by Neville for plain mortar and concrete (22). Such similar relationships may need to be developed for other types of aggregates, different $\mathrm{w} / \mathrm{c}$ ratios and other curing conditions.

\subsubsection{Flexural and splitting tensile strength of mortars and concretes}

Results of flexural strengths of prismatic mortars and splitting tensile strengths of cubic concretes prepared from the produced binders and cured in

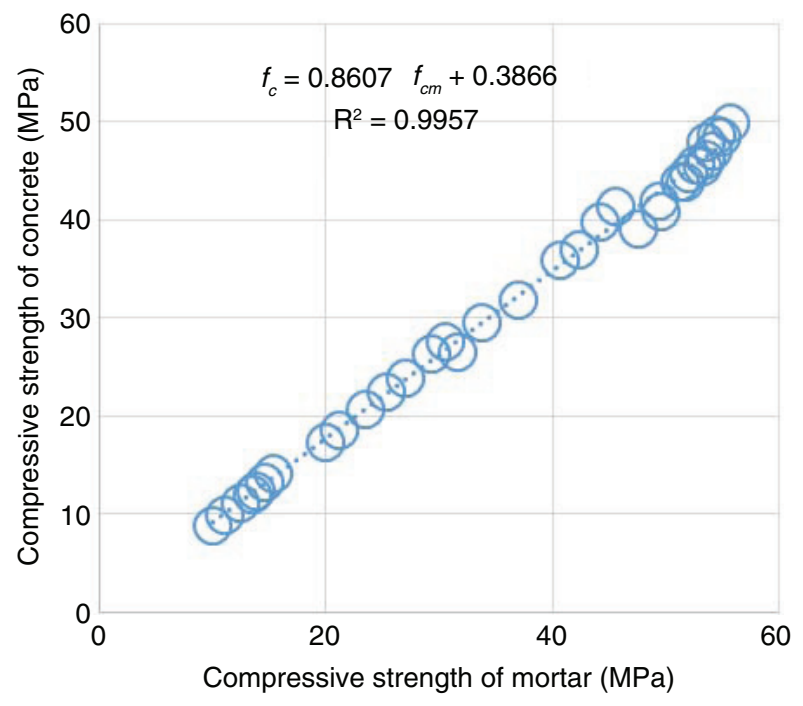

FiguRE 6. Correlation between the compressive strength of concrete and that of mortar of the same $\mathrm{w} / \mathrm{b}$ ratio. water until the test date are arranged in Tables 3 and 4, respectively. A similar trend to that observed for compressive strength seems to be followed by the flexural and splitting tensile strength results. However, the results showed that flexural and splitting tensile strengths were less sensitive than the compressive strength to the volcanic scoria content.

\subsubsection{Correlation between compressive and splitting tensile strength of concretes}

The relationship between the compressive strength $\left(f_{c}\right)$ and splitting tensile strength $\left(f_{s t}\right)$ of concretes is given in Figure 7, and seems to fit well with the relations proposed by Oluokun et al. (26), JCI (27) and AIJ (28) for plain concrete [2]:

$$
f_{s t}=\mathrm{k}\left(f_{c}\right)^{\mathrm{n}}
$$

The correlation between the splitting tensile strength and the compressive strength results was calculated for the entire population of test results and hence the relation obtained is [3]:

$$
f_{s t}=0.195\left(f_{c}\right)^{0.85}
$$

with a regression coefficient of 0.98 . So, knowing the compressive strength $\left(f_{c}\right)$ of concrete the splitting tensile strength $\left(f_{s t}\right)$ can be predicted by using Eq. (3).

\subsection{Water permeability}

Permeability of concrete to water is closely related to the durability of concrete. Permeability is the rate at which aggressive agents penetrate through concrete. Water penetration depth can be considered as

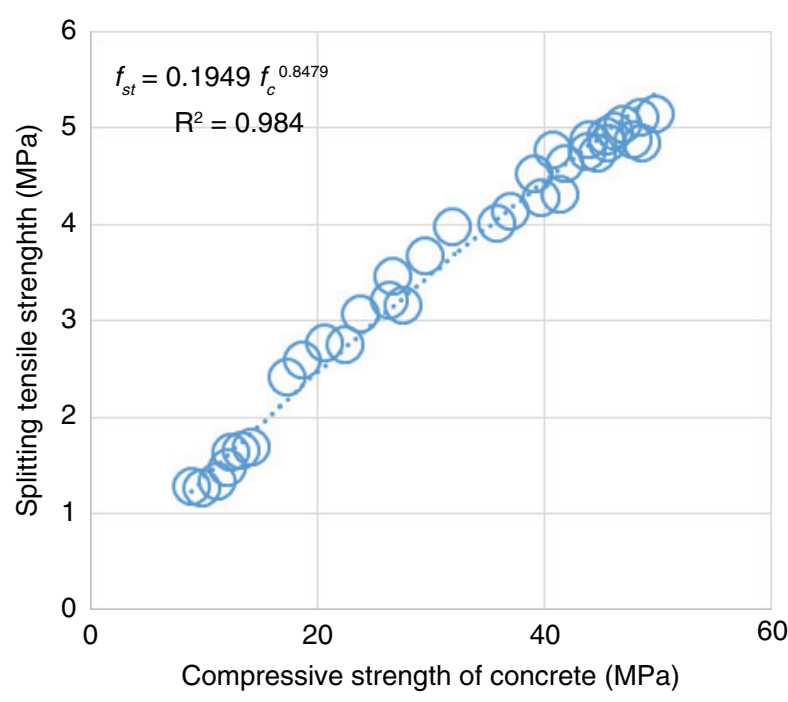

FIGURE 7. Relation between splitting tensile strength and compressive strength of the studied concretes. 
an indication of permeable and impermeable concrete (22). A depth of less than $50 \mathrm{~mm}$ classifies the concrete as impermeable and a depth of less than $30 \mathrm{~mm}$ as impermeable under aggressive conditions (22). Figure 8 shows the water penetration depth test results for all binder types. Concretes containing volcanic scoria-based binders are supposed to have lower permeability than plain Portland cement. But in this research, it has been observed that after 2 day curing, water penetration depths of $\mathrm{C} 2 / 10 \%$ and $\mathrm{C} 3 / 15 \%$ were higher than that of CEM I. Increasing the moist-curing period of concrete from 28 to 90 days reduced water penetration depths of all concretes by a factor ranging from 2.11 to 3.03 for concretes containing scoria-based cements and a lower factor of 1.44 for plain Portland cement concrete. This result is in good agreement with the values reported by Neville for plain concrete (22). None of concretes was found to be impermeable before 28 day curing. However concretes containing 20 to $35 \%$ scoria can be considered as impermeable after 28 day curing, and as impermeable under aggressive environments after 90 day curing, according to Neville (22). However, the concretes containing 10\% and $15 \%$ volcanic scoria needed 180 day curing to achieve this level of impermeability.

\subsection{Chloride penetrability}

From the rapid chloride penetrability test results, as illustrated in Figure 9, it should be noted that C1/CEM I-based concrete permitted almost 2 to 3 times the coulombs charge, compared to the concrete containing $\mathrm{C} 5 / 25 \%, \mathrm{C} 6 / 30 \%$ and $\mathrm{C} 7 / 35 \%$ in spite of the fact that all concretes were made with similar cementitious content and water content. None of the concretes had a total charge less than
2000 coulombs after 2 or 7 day curing. However, the concretes containing binders with volcanic scoria contents of 25,30 and $35 \%$, showed the best performance among all the specimens. According to ASTM C1202, these concretes can be considered as low and very low chloride permeable after 90 and 180 day curing. The improvement in the resistance to chloride penetration may be related to the refined pore structure of these concretes, their reduced electrical conductivity (29) and the secondary pozzolanic reaction which contributes to make the microstructure of concrete denser. This improvement was confirmed by many researchers who investigated natural or other pozzolans, particularly at later curing times (12, 30-32).

\subsection{Porosity}

Porosity of concretes containing different levels of volcanic scoria at various curing times is presented in Figure 10. Porosity of all mixes decreased with curing time. As volcanic scoria is incorporated porosity decreased significantly. Porosity of the concretes containing binders with high replacement levels of volcanic scoria demonstrated much lower porosity as compared to the plain concrete. The rate of decrease in porosity was faster for volcanic scoria-containing concretes as compared to the plain concrete. The reduction in the porosity could be attributed to the pozzolanic reaction between the glassy phase in volcanic scoria and the $\mathrm{CH}$ liberated from hydration of $\mathrm{C}_{3} \mathrm{~S}$ and $\mathrm{C}_{2} \mathrm{~S}$ (12).

The experimental data, depicted in Table 4 and Figs. $8-10$ has been statistically analysed to develop estimation equations to correlate the concrete properties with the curing time and the replacement level of volcanic scoria.

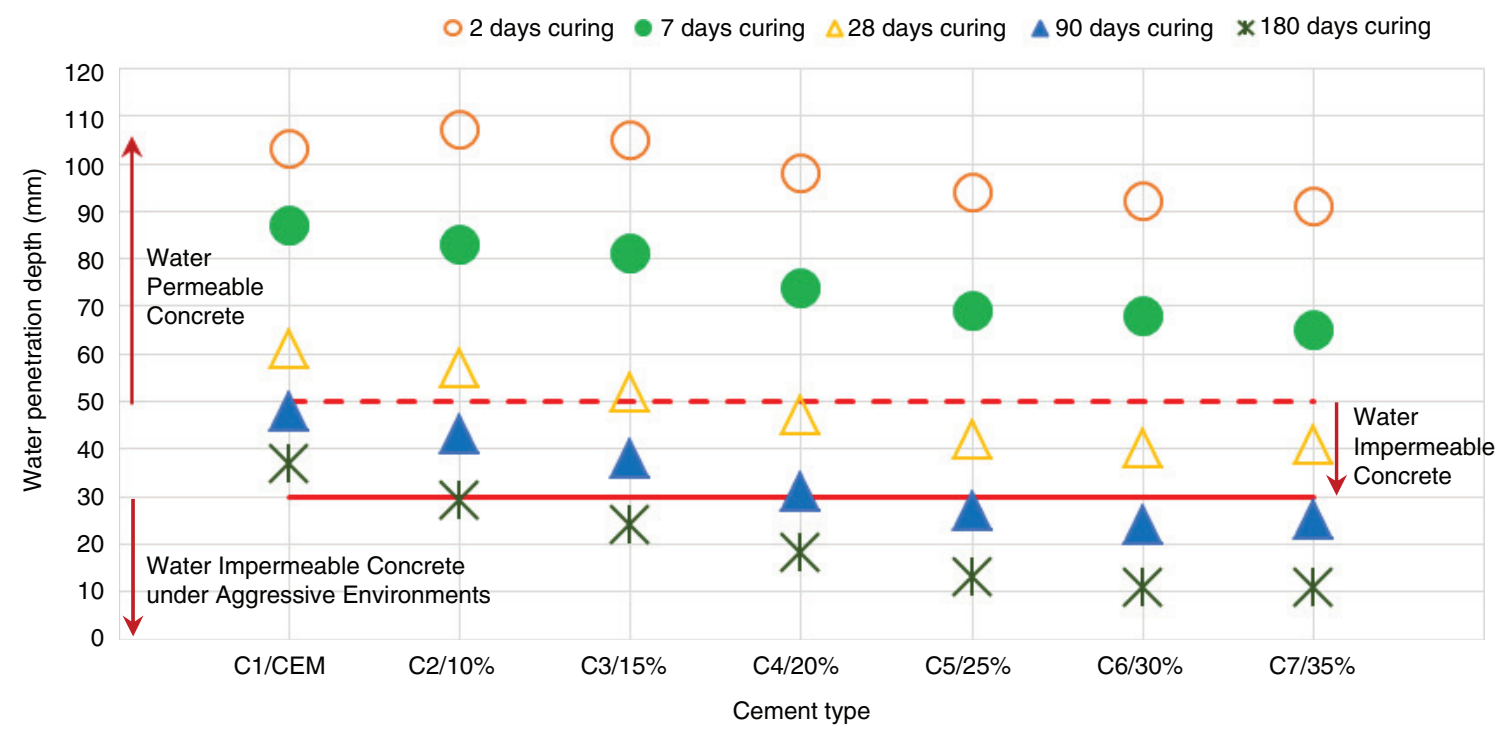

FIGURE 8. Water penetration depths in different concretes cured for 2, 7, 28, 90 and 180 days. 


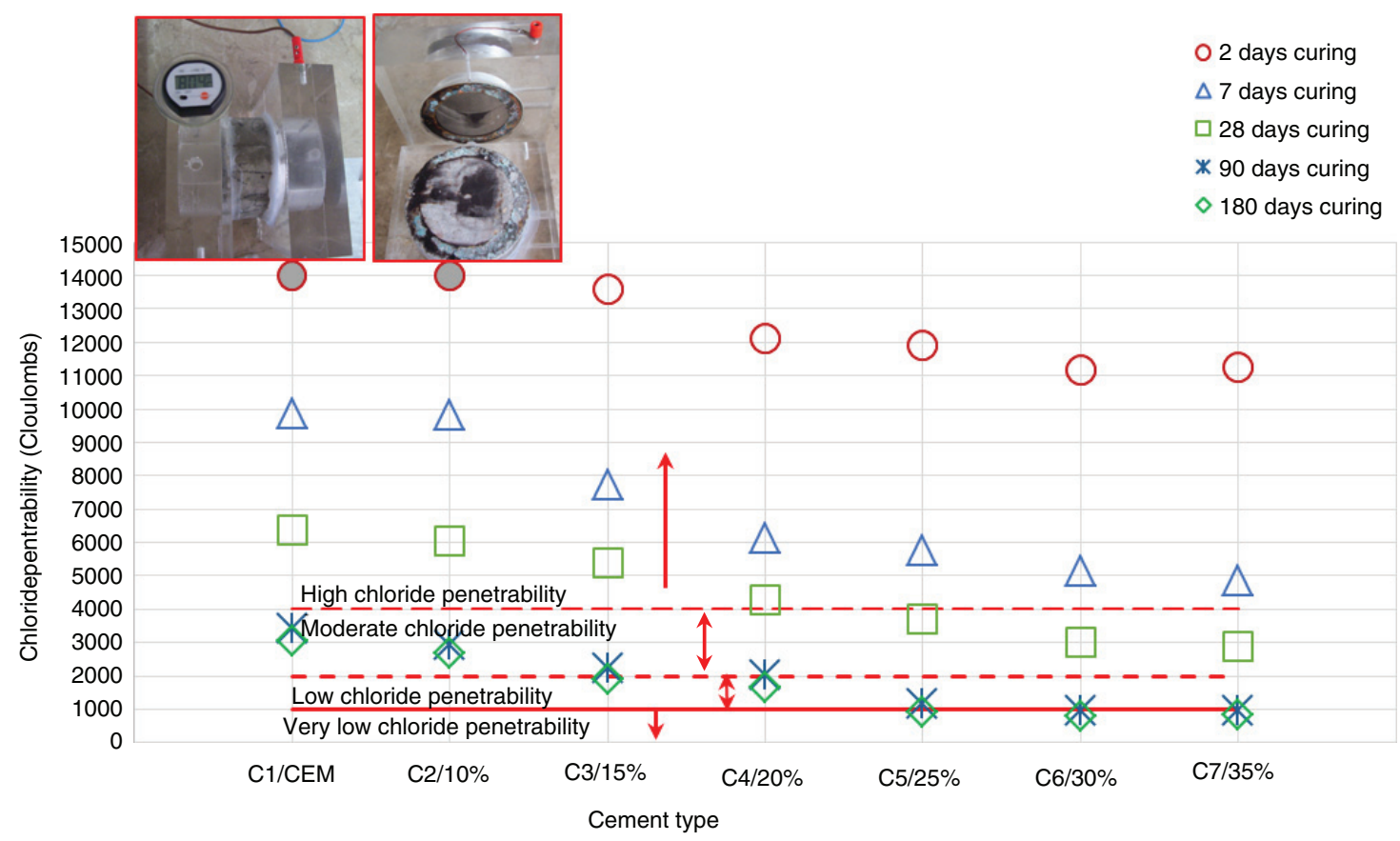

FIGURE 9. Total charge passed through concretes, in Coulombs, after 2, 7, 28, 90 and 180 days curing. (The points for 2 days cured C1/CEM I- \& C2/10\%-based concrete specimens were solid filled. The test of these specimens was terminated after about 5.5 hours because of the high temperature of the cell's solution and the highly penetrable concretes, as in the photos shown above)

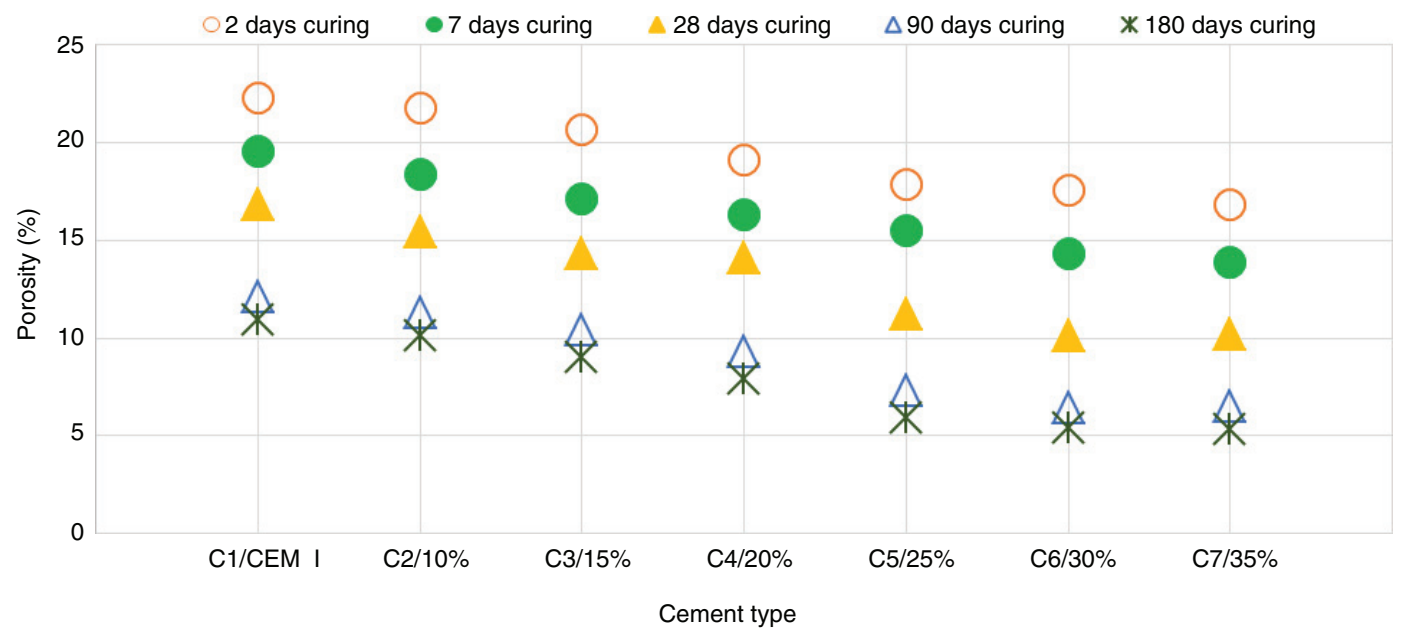

FIGURE 10. Porosity of concretes with different levels of volcanic scoria after 2, 7, 28, 90 and 180 days curing.

The equations can be expressed by the following single formula [4]:

$$
C P=a_{1}+a_{2} \times V S+a_{3} \times \ln t+a_{4} \times V S \times \ln t
$$

where $C P$ is the concrete property (i.e., compressive strength, water permeability, chloride penetrability and porosity); VS is the percentage of volcanic scoria in the binder; $t$ is the curing time; $a_{1}, a_{2}, a_{3}$ and $a_{4}$ are constants.

The constants have been obtained through the regression analysis of the data in Table 4 and Figs. 8-10.
The best-fit values of constants $a_{1}, a_{2}, a_{3}$ and $a_{4}$ and the regression coefficients $R^{2}$ of the correlation between the measured and the proposed values are presented in Table 5. The results indicated excellent relationships between the curing time and the properties of concrete with different replacement levels of volcanic scoria.

It is to be noted that the correlation equation developed in the present work would be helpful for concrete mix designers. However, it should be noted that the relationship reported in the paper have been developed for concrete containing dolomite aggregates, having w/c ratio of 0.5 and cured at ambient 
TABLE 5. Constants $\mathrm{a}_{1}, \mathrm{a}_{2}, \mathrm{a}_{3}$ and $\mathrm{a}_{4}$ and regression coefficients $\left(\mathrm{R}^{2}\right)$ of the correlation between the measured and calculated values according to the proposed equation

\begin{tabular}{lrcccc}
\hline & \multicolumn{4}{c}{ Constants } & Regression coefficient $\left(R^{2}\right)$ \\
\cline { 2 - 5 } Concrete property (CP) & $a_{1}$ & $a_{2}$ & $a_{3}$ & $a_{4}$ & 0.98 \\
\hline Compressive strength (MPa) & 12.3 & -0.27 & 8.4 & -0.02 & 0.99 \\
Water penetration depth (mm) & 124.2 & -0.705 & -17.3 & -0.011 & 0.92 \\
Chloride Penetrability (Coulombs) & 16461 & -171 & -2713 & 16.34 & 0.98 \\
Porosity (\%) & 25.4 & -0.196 & -2.577 & -0.003 & \\
\hline
\end{tabular}
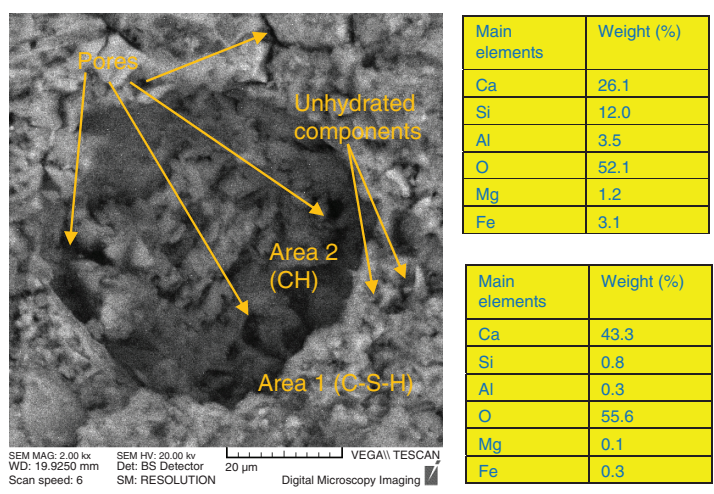

FIGURE 11. SEM/EDX analysis results of 7 days cured C6/30\%-based paste.

temperatures. Such similar relationships may need to be developed for other types of aggregates, different $\mathrm{w} / \mathrm{c}$ ratios and other curing conditions.

From the results obtained, volcanic scoria showed significant improvement which clearly indicated that the volcanic scoria was efficient in the refinement of pore size distribution. This has been reflected in the reduction of water permeability and porosity.

The results have been confirmed using the SEM/ EDX techniques, as shown in Figs. 11-13. The microstructural and EDX analysis of 7 day cured C6/30\% paste, Figure11, revealed a non-compacted structure. On the other hand, after 28 and 90 day curing, Figures 12 and 13, the microstructural analysis of $\mathrm{C} 6 / 30 \%$ paste showed denser and more compacted structure due to the progress of the cement hydration. In addition, the EDX analysis results clearly indicated the formation of cementitious phases, such as calcium silicate hydrates $(\mathrm{C}-\mathrm{S}-\mathrm{H})$ and calcium alumino-silicate-hydrates (C-A-S-H). These might be formed through the continuation of cement hydration and the progress of the pozzolanic reaction between the amorphous phases in volcanic scoria and $\mathrm{CH}$ (calcium hydroxide) released during cement hydration (33).

\section{CONCLUSION}

-The volcanic scoria quarried from the studied site is considered suitable for making blended cements. It had major chemical components,
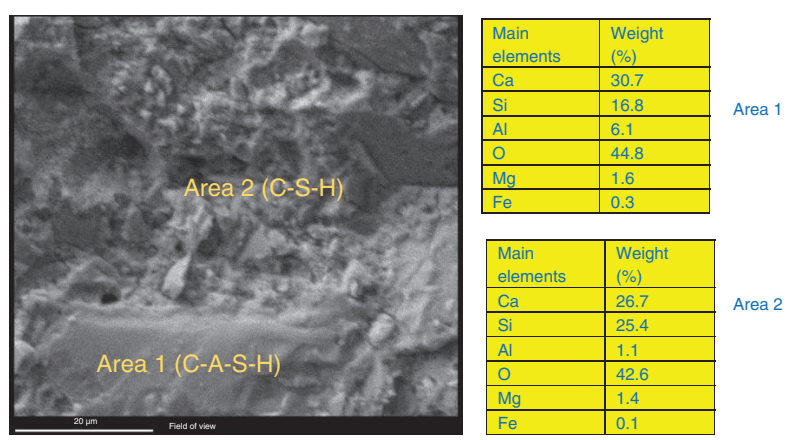

FIGURE 12. SEM/EDX analysis results of 28 days cured C6/30\%-based paste.
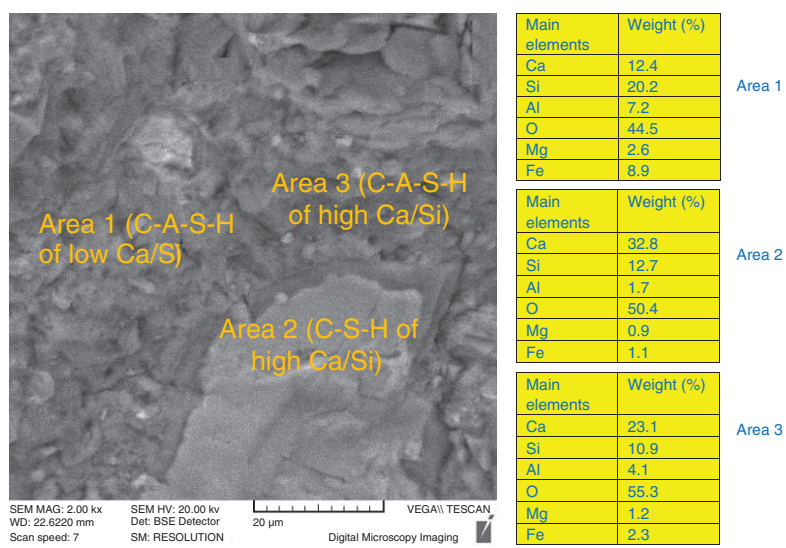

FIGURE 13. SEM/EDX analysis results of 90 days cured C6/30\%-based paste.

$\mathrm{SiO}_{2}+\mathrm{Al}_{2} \mathrm{O}_{3}+\mathrm{Fe}_{2} \mathrm{O}_{3}$, conforming to the chemical requirements of the ASTM and EN standards. The binders containing volcanic scoria were in conformity with the standard requirements.

-The compressive strengths of mortars and concretes containing scoria-based binders were much lower than those of plain cement mortar and concrete at all early ages of concrete. However, after 90 and 180 day curing, the compressive strengths of scoria-based binder mortars and concretes were comparable to those of plain cement concrete.

-Water permeability, chloride penetrability and porosity of scoria-based concrete mixes were much lower than those of plain concrete, especially at 
longer curing time and high replacement levels of scoria. This has also been confirmed by SEM/EDX analysis.

-A definite correlation was observed between the compressive strength of concretes and that of mortars with a similar w/b ratio, such that one can be estimated from knowledge of the other.

-Curing time had a large influence on both strength and durability properties of scoria-based binder concrete. However, the consequences of bad curing can be more serious for the latter.

-The assumption that 'strong concrete is durable concrete' is not always true. Scoria-based binder concretes had lower compressive strengths, but greater resistance to water and chloride penetration compared to plain cement concretes at almost all curing times.

-Estimation equations for predicting the investigated concrete properties (i.e. compressive strength, water penetration depth, chloride penetration and porosity) incorporating the effect of curing time and the replacement level of volcanic scoria were derived. These equations permit the concrete properties of scoria-based concretes to be predicted with a high degree of accuracy $\left(\mathrm{R}^{2} \geq 0.92\right)$. However, they were limited to the $\mathrm{w} / \mathrm{c}$ ratio of 0.5 .

\section{ACKNOWLEDGEMENT}

The authors gratefully acknowledge the technical and financial support of this research from the management of General Organization for cement \& Building Materials/Adra Cement Plant. Thanks are also expressed to Prof. Tamer al-Hajeh, Vice-President of AIU, for his appreciated help.

\section{REFERENCES}

1. Ramezanianpour A.A. (2014) Cement replacement materials: Properties, durability, sustainability. Springer-Verlag Berlin Heidelberg.

2. Aitcin, P.C.; Mindess, S. (2011) Sustainability of concrete. Spon Press.

3. Hooton, RD.; Bickley, JA. (2014) Design for durability: The key to improving concrete sustainability. Constr. Build. Mater. 67, 422-430. http://dx.doi.org/10.1016/J. conbuildmat.2013.12.016.

4. Owaid, H.M.; Hamid, R.B.; Taha, M.R. (2012) A review of sustainable supplementary cementitious materials as an alternative to all-Portland cement mortar and concrete. Aust. J. Basic Appl. Sci. 6 [9], 2887-2303.

5. Al-Chaar, G.K.; Al-Kadi, M.; Asteris, P.G. (2013) Natural pozzolan as a partial substitute for cement in concrete. The Open Constr. Technol. J. 7, 33-42.

6. Senhadji, Y.; Escadeillas, G.; Khelafi, H.; Mouli, M.; Benosman, A.S. (2012) Evaluation of natural pozzolan for use as supplementary cementitious material. Eu.J. Environ. Civ. Eng. 16 [1], 77-96. http://dx.doi.org/10.1080/19648189. 2012.667692.

7. Hossain, K.M.A. (2009) Resistance of scoria-based blended cement concrete against deterioration and corrosion in mixed sulfate environment. ASCE J. Mater. Civ. Eng. 21 [7], 299-308. http://dx.doi.org/10.1061/(ASCE) 0899-1561(2009)21:7(299).
8. Ghrici, M.; Kenai, S.; Meziane E. (2006) Mechanical and durability properties of cement mortar with Algerian natural Pozzolana. J. Mater. Sci. 41, 6965-6972. http://dx.doi. org/10.1007/s10853-006-0227-0.

9. Cavdar, A.; Yetgin, S. (2007) Availability of tuffs from northeast of Turkey as natural pozzolans on cement, some chemical and mechanical relationships. Constr. Build. Mater. 21, 2066-2071. https://doi.org/10.1016/j. conbuildmat.2006.05.034.

10. Turanli, L.; Uzal, B.; Bektas, F. (2005) Effect of large amounts of natural pozzolan addition on properties of blended cements. Cem. Concr. Res. 35 [6], 1106-1111. http://dx.doi.org/10.1016/j.cemconres.2004.07.022.

11. Rodriguez-Camacho, R.E.; Uribe-Afif, R. (2002) Importance of using natural pozzolans on concrete durability. Cem. Concr. Res. 32, 1851-1858. http://dx.doi. org/10.1016/S0008-8846(01)00714-1

12. Khan, M.I.; Alhozaimy, A.M. (2011) Properties of natural pozzolan and its potential utilization in environmental friendly concrete. Can. J. Civ. Eng. 38, 71-78. http://dx.doi. org/10.1139/L10-112.

13. Massazza, F. (2008) Structure and performance of cements. edited by Benested J., and Barnes, second edition. Taylor \& Francis. 2008

14. The General Establishment of Geology and Mineral Resources in Syria (GEGMR) (2011) A Guide for mineral resources in Syria. (in Arabic).

15. The General Establishment of Geology and Mineral Resources in Syria (GEGMR) (2007) Official document nr. (3207/T/9) dated 21.11.2007. (in Arabic).

16. The General Organization for Cement and Building Materials (GOCBM) http://cemsyria.com.sy. Accessed in 2011 (in Arabic).

17. Binici, H.; Aksogan, O.; Cagatay, JH.; Tokyay, M.; Ensen, E. (2007) The effect of particle size distribution on the properties of blended cement. Powder Technol. 177, 140-147. http://dx.doi.org/10.1016/j.powtec.2007.03.033

18. Yetgin, S.; Cavdar, A. (2006) A study of effects of natural pozzolan on properties of cement mortars. ASCE J. Mater. Civ. Eng. 18 [6], 813-816. https://doi.org/10.1061/ (ASCE)0899-1561(2006)18:6(813)

19. Pourkhorshidi, A.R.; Najimi, M.; Parhizkar, T.; Jafarpour, F: Hillemeier, B. (2010) Applicability of the standard specification of ASTM C618 for evaluation of natural pozzolans. Cem. Concr. Comp. 32, 794-800. http://dx.doi. org/10.1016/j.cemconcomp.2010.08.007.

20. Adesanya, D. A.; Raheem, A.A. (2009) Development of corn cob ash blended cement. Constr. Build. Mater. 23 [1], 347-352. http://dx.doi.org/10.1016/j.conbuildmat.2007.11.013.

21. Colak, A. (2003) Characteristics of pastes from a Portland cement containing different amounts of natural pozzolan. Cem. Concr. Res. 33, 585-593. http://dx.doi.org/10.1016/ S0008-8846(02)01027-X.

22. Neville, A.M. (2011) Properties of concrete. Fifth edition, Pearson Education.

23. Hossain, K.M.A. (2003) Blended cement using volcanic ash and pumice. Cem. Concr. Res. 33, 1601-1605. 2003. http://dx.doi.org/10.1016/s0008-8846(03)00127-3.

24. Mehta, P.K. and Monteiro, PJM. (2006) Concrete: Microstructure, properties, and Materials. $3^{\text {rd }}$ edition. McGraw-Hill.

25. Montgomery D.C. and Peck E.A. (1982) Introduction to linear regression analysis. New York: Wiley.

26. Oluokun, F.A; Burdette, E.G.; Deatherage, J.H. (1991) Splitting tensile strength and compressive strength relationships at early ages. ACI Mater. J. 88 [2], 115-121.

27. JCI. (2011) Guidelines for control of cracking of mass concrete 2008. Japan Concrete Institute.

28. AIJ. (2008) Recommendations for practice of thermal cracking control of massive concrete in building. Architectural Institute of Japan.

29. Talbot, C.; Pigeon, M.; Maarchand, M.; Hornain, J. (1995). Properties of mortar mixtures containing high amounts of various supplementary cemetitious materials. In: Proceedings of the fifth international conference on the 
Production of more durable and sustainable concretes using volcanic scoria as cement replacement 13

use of fly ash, silica fume, slag, and natural pozzolana in concrete, edited by Malhotra, VM. ACI SP 153, 125-152.

30. Rukzon, S.; Chindaprairt, P. (2009) Effect of grinding on chemical and physical properties of rice husk ash. Int. J. Miner Metal Mater. 16 [2], 242-247. http://dx.doi. org/10.1016/S1674-4799(09)60041-8.

31. Chinaprasirt, P.; Chotithanorm, C.; Cao, H.; Sirivivatnanon, V. (2007) Influence of fly ash fineness on the chloride penetration of concrete. Constr. Build. Mater. 21, 356-361. http://dx.doi.org/10.1016/j.conbuildmat.2005.08.010.

32. Gastaldini, A.; Isaia, G.; Gomes, J.; Sperb, J. (2007) Chloride penetration and carbonation in concrete with rice husk ash and chemical activation. Cem. Concr. Comp. 29 [3], 176-180. https://doi.org/10.1016/j.cemconcomp.2006.11.010

33. Mindess, S.; Young, J.; Darwin, D. (2003) Concrete. 2nd edition, Prentice Hall. 